\title{
DOES SCHOOL ENVIRONMENT AFFECT THE RISK OF OVERWEIGHT IN HIGH SCHOOL STUDENTS? A NEW EVIDENCE FROM KARANGANYAR, CENTRAL JAVA, INDONESIA
}

\author{
Aris Widiyanto'), Bhisma Murti'2), RB. Soemanto3) \\ 1)School of Health Sciences Mambaul Ulum,Surakarta \\ ${ }^{2)}$ Masters Program in Public Health,Universitas Sebelas Maret \\ 3)Faculty of Social and Political Sciences,Universitas Sebelas Maret
}

\begin{abstract}
Background: Studies have shown that adolescent obesity is associated with greater risks of adverse health in severely obese adults. As the Basic Health Research (RISKESDAS) has reported the prevalence of overweight in adolescent aged 13-15 in Indonesia in 2013 was $10.8 \%$. Karanganyar district is ranked fourth by the number of overweight adolescents cases in Central Java with prevalence of 8.2\%. This study aimed to test the hypothesize if school environment affect the risk of overweight in high school students in Karanganyar, Central Java, Indonesia, after controlling for the counfounding factors such as socio-cultural and lifestyle factors, using multilevel analysis.

Subjects and Method: This was a cross-sectional study conducted at 25 junior high schools in Karanganyar district, Central Java, in December 2017. A sample of 200 junior high school students were selected for this study by stratified sampling and fixed disease sampling. The dependent variable was overweight. The independent variables were nutritional intake, snacking habits, physical activity, self efficacy, paternal BMI, maternal BMI, peer group influence, and school environment. Body weight data was measured by digital scale. Contextual effect of school environment was measured by the number of snack sellers at school. Other data were collected by questionnaire and analyzed by multilevel analysis.

Results: High nutritional intake $(b=1.56, \mathrm{SE}=0.73, \mathrm{p}=0.032)$, high snacking habits $(b=1.27, \mathrm{SE}=0.70 ; \mathrm{p}=0.069)$, paternal $\mathrm{BMI} \geq 23(\mathrm{~b}=1.60 ; \mathrm{SE}=0.79 ; \mathrm{p}=$ $0.042)$, maternal $\mathrm{BMI} \geq 23(\mathrm{~b}=2.29 ; \mathrm{SE}=0.76 ; \mathrm{p}=0.002)$, parent income $\geq$ minimum regional wage $(\mathrm{b}=2.17 ; \mathrm{SE}=0.76 ; \mathrm{p}=0.004)$, and strong peer group influence $(b=2.22 ; \mathrm{SE}=0.65 ; \mathrm{p}=0.001)$ increased the risk of overweight in adolescents. High self-efficacy $(b=-3.61 ; \mathrm{SE}=0.75 ; \mathrm{p}<0.001)$ and high physical activity $(b=-2.92 ; \mathrm{SE}=0.80 ; \mathrm{p}<0.001)$ decreased the risk of overweight in adolescents. Intra-class correlation $=9.92 \%$ indicating considerable contextual effect of school environment.

Conclusion: School environment has a considerable contextual effect on overweight in adolescents. In addition, nutritional intake, snack habits, paternal $\mathrm{BMI}$, maternal BMI, family income, and peer influence increase the risk of overweight in adolescent. Self-efficacy and high physical activity decrease the risk of overweight in adolescent.
\end{abstract}

Keywords: overweight, social cultural factor, adolescents, school environment

\section{Correspondence:}

Aris Widiyanto. School of Health Sciences Mambaul Ulum, Surakarta.

Email: widiyanto.aris99@gmail.com. Mobile: 081329209095. 